\title{
RGS7 wt Allele
}

National Cancer Institute

\section{Source}

National Cancer Institute. RGS7 wt Allele. NCI Thesaurus. Code C143119.

Human RGS7 wild-type allele is located in the vicinity of $1 \mathrm{q} 43$ and is approximately $582 \mathrm{~kb}$ in length. This allele, which encodes regulator of G-protein signaling 7 protein, is involved in the stimulation of $\mathrm{G}$ alpha activation. 